\title{
Production of a Spirulina sp. algae hybrid with a silica matrix as an effective adsorbent to absorb crystal violet and methylene blue in a solution
}

\author{
Buhani $^{1 *}$, Suharso ${ }^{1}$, Ismi Aditiya ${ }^{1}$, Radho Al Kausar ${ }^{1}$, Sumadi $^{2}$ and Rinawati ${ }^{1}$
}

\begin{abstract}
In this study, the adsorbent of Crystal Violet (CV) and Methylene Blue (MB) dyes was synthesized from the hybridization of Spirulina sp. algae biomass with silica as a matrix (ASS). Hybridization of Spirulina sp. algae biomass was carried out through a sol-gel process using tetraethyl orthosilicate precursors. The ASS adsorbent was characterized using Fourier-transform infrared spectroscopy, X-ray diffraction, Brunauer-Emmett-Teller surface area method and scanning electron microscopy-energy-dispersive-X ray. The CV and MB dyes adsorption onto ASS adsorbent was studied through adsorption experiments using the batch method. The optimum adsorption of CV and $\mathrm{MB}$ dyes is at $\mathrm{pH}$ of 8 and contact time of $60 \mathrm{~min}$. The CV and MB dye kinetics on the ASS adsorbent tend to follow the pseudo-second-order kinetics model with rate constant $\left(k_{2}\right)$ of 0.3 and $0.2\left(\mathrm{~g} \mathrm{mg}^{-1} \mathrm{~min}^{-1}\right)$ respectively. The isotherm adsorption pattern of $\mathrm{CV}$ and $\mathrm{MB}$ dyes follows the Freundlich adsorption isotherm with $K_{F}$ values of 1.07 and $1.05\left(\mathrm{mg} \mathrm{g}^{-1}\right)\left(\mathrm{L} \mathrm{mg}^{-1}\right)^{1 / n}$, respectively. In the simultaneous adsorption process, $\mathrm{CV}$ dyes were more adsorbed than MB in solution to the ASS adsorbent.
\end{abstract}

Keywords: Algae-silica hybrid, Spirulina sp. algae, Crystal violet, Methylene blue, Adsorption

\section{Introduction}

Methylene Blue (MB) and Crystal Violet (CV) are dyes that are widely used as coloring agents in various industrial fields such as the textile, paper, leather, and pharmaceutical industries. Most synthetic dyes and their degradation products have a large environmental impact, especially in aquatic environments due to their extensive use and low level of waste treatment [1]. After the dye enters the wastewater, the mixture becomes more stable and more difficult to decompose due to the complex chemical structure formed [2]. Color substances can cause an increase in Biological Oxygen Demand even though dyestuffs only make a small contribution to the total organic load in wastewater [3].

$\mathrm{CV}\left(\mathrm{C}_{25} \mathrm{~N}_{3} \mathrm{H}_{30} \mathrm{Cl}\right)$ is widely used as a dermatological agent in various commercial textile processes [4] while

\footnotetext{
*Correspondence: buhani_s@yahoo.co.id

${ }^{1}$ Department of Chemistry, University of Lampung, Bandar Lampung 35145, Indonesia

Full list of author information is available at the end of the article
}

$\mathrm{MB}\left(\mathrm{C}_{16} \mathrm{H}_{18} \mathrm{~N}_{3} \mathrm{SCl}\right)$ is a cationic dye of aromatic hydrocarbon compound. Both are two types of cationic dyes which are stable to light and heat and difficult to decompose due to complex structures [5, 6]. Although both have many benefits in different uses, $\mathrm{CV}$ and $\mathrm{MB}$ dyes are mutagenic and toxic [7-10]. Therefore, it is necessary to reduce the concentration of these dyes in industrial waste, especially in the treatment of waste before the spread to the environment occurs.

The processing of $\mathrm{CV}$ and $\mathrm{MB}$ dyes waste has been carried out through several processes such as oxidation [11], coagulation and flocculation [12], adsorption [13, 14] and ion exchange [15]. The adsorption process is one of the right ways to treat waste containing dyes and heavy metals before being discharged into the environment, because the adsorption method is simple, relatively inexpensive, and does not cause side products that are harmful to the environment $[16,17]$. The success of the adsorption process is largely determined by the suitability of the properties 
and types of adsorbents used. Effective adsorbents for adsorption are those having a large adsorption rate and capacity, are chemically stable, can be used repeatedly, and are environmentally friendly $[1,14]$.

Algae biomass naturally is a highly effective adsorbent to remove pollutants from organic compounds derived from dyes $[18,19]$. However, the ability of algae to bind the chemical compounds is limited by several constraints such as small size, low specific gravity and easily damaged due to degradation by other microorganisms [20, 21]. In addition, the algae cannot be used directly in the adsorption column, because it is very soft and not granular [22, 23]. To overcome these weaknesses, various efforts have been made, among others, by immobilizing algae biomass using various supporting polymers such as silica [24].

The sol-gel process is an appropriate process for immobilizing various organic molecules, organometallics, and biomolecules in inorganic matrix. The sol-gel method is one of method applied to transform a silica surface via a homogeneous way to result in organo-silica hybrid substances. In fact, the sol-gel technique has been used to modify algae biomass to homogeneous adsorbents [25]. In this study, it was carried out immobilization of Spirulina sp. biomass with a silica matrix derived from tetraethyl orthosilicate (TEOS) producing adsorbents (termed ASS) to absorb CV and MB dyes in solution. The CV and MB dyes adsorption was studied including the effect of solution $\mathrm{pH}$, contact time, and concentration of dye adsorbed by the ASS adsorbent.

\section{Materials and methods Materials}

Spirulina sp. algae biomass which was used as an adsorbent in this study was obtained from the Lampung Marine Aquaculture Development Center, Indonesia. The chemicals used in this research were of analytical grade. TEOS, ethanol, ammonia, hydrochloric acid $(\mathrm{HCl})$, sodium hydroxide, $\mathrm{CV}, \mathrm{MB}$, and $\mathrm{CH}_{3} \mathrm{COONa}$ were purchased from Pharmacopoeia European.

A stock solution of $1 \mathrm{~g} \mathrm{~L}^{-1}$ of the $\mathrm{CV}$ and $\mathrm{MB}$ dye was prepared. For the present study, the CV or MB dye concentrations between 10 and $400 \mathrm{ppm}$ were prepared from the stock solution. The CV dye showed absorbance in the $\lambda_{\max }=595 \mathrm{~nm}$ and the MB dye showed absorbance in the $\lambda_{\max }=664 \mathrm{~nm}$ (UV-Vis spectrophotometer, Agilent Cary 100). All experiments were performed using double distilled water.

\section{Preparation of ASS adsorbent}

The harvest of Spirulina sp. algae biomass was obtained from cultivation in a laboratory scale at the Lampung Marine Aquaculture Development Center, Indonesia.
The algae biomass was dried to constant weight in an oven at temperature of $40^{\circ} \mathrm{C}$, then smoothed by grinding to a size of $100-200$ mesh $(74-149 \mu \mathrm{m})$.

The preparation of ASS adsorbents was carried out according to the procedure of synthesis of algae-silica hybrids [26], namely reacting with $5 \mathrm{~mL}$ of TEOS and 2.5 $\mathrm{mL}$ of distilled water in a plastic bottle, then stirring with a magnetic stirrer for $30 \mathrm{~min}$ and added $1 \mathrm{M} \mathrm{HCl}$ to $\mathrm{pH}$ of 2. In another plastic container, $0.4 \mathrm{~g}$ of Spirulina sp. algae biomass were mixed with $5 \mathrm{~mL}$ of ethanol and then stirred with a magnetic stirrer for $30 \mathrm{~min}$. Both solutions were then mixed and stirred using a magnetic stirrer until a gel was formed. The gel formed was filtered, then let stand for $24 \mathrm{~h}$. The gel was then washed with distilled water and ethanol (60:40) to neutral $\mathrm{pH}$. The gel was dried using an oven and then crushed to a size of 100-200 mesh $(74-149 \mu \mathrm{m})$.

\section{Characterization of ASS adsorbent}

The ASS adsorbent was characterized by Fouriertransform infrared spectroscopy (FTIR) to identify its functional group (Shimadzu Prestige-21 IR). Analysis of pore volumes and specific surface area was investigated using a surface area analyzer (Quantachrome TouchWin v1.0). The constituent elements and surface morphology were identified by scanning electron microscopy-energydispersive-X ray spectroscopy (SEM-EDX, Zeiss MA10).

\section{Adsorption experiments}

A series of $\mathrm{CV}$ and $\mathrm{MB}$ dyes adsorption experiments in solution using the ASS adsorbent were carried out in the batch method according to procedures reported by Buhani et al. [14]. The effect of $\mathrm{pH}$ of the solution was studied with variations in $\mathrm{pH}$ of $2-10$, contact time of 0-90 min, and initial concentration of $0-400 \mathrm{mg} \mathrm{L}^{-1}$ at a temperature of $27^{\circ} \mathrm{C}$. The data obtained were analyzed to determine kinetics and adsorption isotherm model of the $\mathrm{CV}$ and $\mathrm{MB}$ dyes.

The quantity of $\mathrm{CV}$ and $\mathrm{MB}$ dye molecules adsorbed per mass unit of adsorbent was determined using Eq. (1). The percentage of $\mathrm{CV}$ and $\mathrm{MB}$ dyes adsorbed on ASS adsorbent was determined using Eq. (2).

$$
\begin{aligned}
& q=\frac{\left(C_{o-} C_{e}\right) v}{w} \\
& \text { Removal }(\%)=\frac{\left(C_{o-} C_{e}\right)}{C_{o}} \times 100
\end{aligned}
$$

where $C_{o}$ and $C_{e}\left(\mathrm{mg} \mathrm{L}^{-1}\right)$ is the $\mathrm{CV}$ or MB dye concentration before and after the adsorption process, $w$ is the quantity of adsorbent (g), and $v$ is the volume of solution (L), $q$ is the amount of $\mathrm{CV}$ or MB dye adsorbed per unit mass $\left(\mathrm{mg} \mathrm{g}^{-1}\right)$. 


\section{Results and discussion}

\section{Characterization of ASS adsorbent}

The characterization of the ASS adsorbent was carried out using IR spectroscopy, SEM-EDX, and BET surface area method to determine the success of making ASS material from Spirulina sp. algae biomass with silica matrix from TEOS as a precursor.

From the FTIR spectra of the adsorbent shown in Fig. 1, it can be seen that the specific absorption of silica (SG) is the absorption band of $462.9 \mathrm{~cm}^{-1}$ showing the bending vibration of the siloxane ( $\mathrm{Si}-\mathrm{O}-\mathrm{Si}$ ) group. The absorption band at around of $786.7 \mathrm{~cm}^{-1}$ indicates the symmetrical stretching vibration of $\mathrm{Si}-\mathrm{O}$ in siloxane. The absorption intensity at $964.4 \mathrm{~cm}^{-1}$ comes from stretching vibrations of -Si-O- from -Si-OH and strong absorption bands at $1072.9 \mathrm{~cm}^{-1}$ show the asymmetric stretching vibration of $\mathrm{Si}-\mathrm{O}$ from siloxane ( $\mathrm{Si}-\mathrm{O}-\mathrm{Si})$ [27].

In the spectrum, Spirulina sp. algae biomass is shown at absorption band of $3387 \mathrm{~cm}^{-1}$ which indicates that the group $(-\mathrm{OH})$ overlaps with $\mathrm{N}-\mathrm{H}$. The absorption shows the presence of a group $(-\mathrm{OH})$ derived from polysaccharides or groups $(\mathrm{N}-\mathrm{H})$ of proteins contained in the biomass of Spirulina sp. algae. The wavenumber at 2931.8 $\mathrm{cm}^{-1}$ shows the presence of $\mathrm{C}-\mathrm{H}$ stretching vibration of aliphatic $\left(-\mathrm{CH}_{2}\right)$. The carbonyl group $(\mathrm{C}=\mathrm{O})$ was detected at $1658.8 \mathrm{~cm}^{-1}$ and $1026.1 \mathrm{~cm}^{-1}$ showed the presence of -C-O group from the cellulose structure which is the absorption characteristic of Spirulina sp. algae biomass.
The ASS adsorbent provides significant FTIR uptake, namely the emergence of a typical absorption band of $\mathrm{SiO}_{2}$ at $1087.9 \mathrm{~cm}^{-1}$ which is $\mathrm{Si}-\mathrm{O}$ asymmetrical stretching vibration on siloxane bonds while absorption at $794.7 \mathrm{~cm}^{-1}$ is $\mathrm{Si}-\mathrm{O}$ symmetrical stretching vibration of the group siloxane. Uptake at $450 \mathrm{~cm}^{-1}$ shows the bending vibrations of $\mathrm{Si}-\mathrm{O}-\mathrm{Si}$ and the absorption peak in the area of $3400 \mathrm{~cm}^{-1}$ indicates the $-\mathrm{OH}$ stretching vibration of silanol $(\mathrm{Si}-\mathrm{OH})$. The hybridization process with Spirulina sp. algae biomass is reflected by the emergence of $\mathrm{C}-\mathrm{H}$ absorption band characteristics from aliphatic $\left(-\mathrm{CH}_{2}\right)$ at $2931.8 \mathrm{~cm}^{-1}$ [17]. This is confirmed by the loss of $\mathrm{Si}-\mathrm{O}$ stretching vibration from $\mathrm{Si}-\mathrm{OH}$ observed at $964.4 \mathrm{~cm}^{-1}$ caused by the reduction of the silanol group due to condensation that occurs with the biomass of Spirulina sp. algae [27-29].

Figure 2 shows the SEM image and EDX spectrum of the material resulted from Spirulina sp. biomass hybridization with silica through a sol-gel process. The analysis results of SEM showed the surface morphology of the ASS adsorbent in the form of amorphous solids whereas in the EDX spectrum there were several elements that dominated the ASS material composition, namely $\mathrm{Si}, \mathrm{O}, \mathrm{C}$, and $\mathrm{H}$, indicating a hybridization process between the silica matrix and the Spirulina sp. algae biomass [26].

In Fig. 3 it can be seen that the pattern of the $\mathrm{N}_{2}$ adsorption-desorption isotherm in the ASS follows the

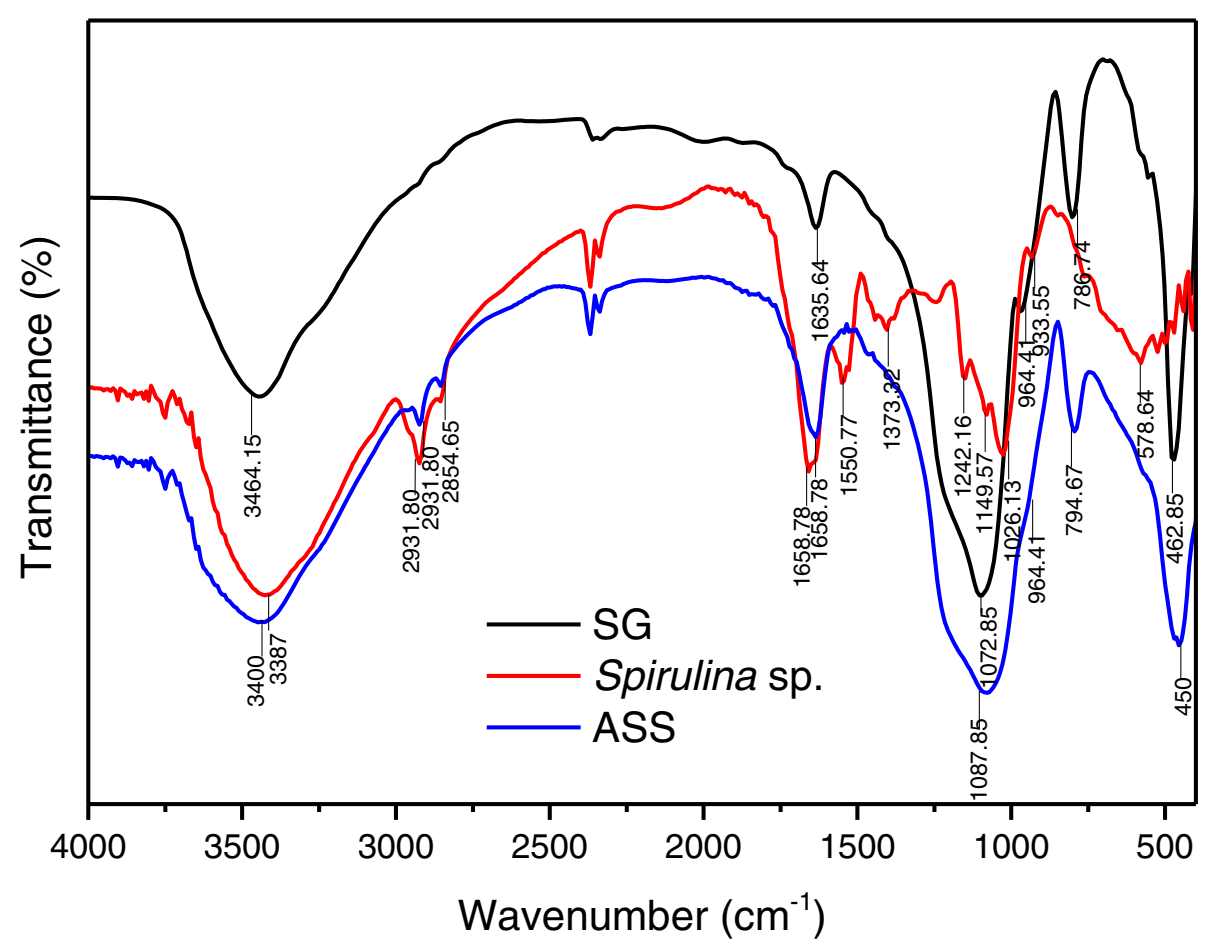

Fig. 1 FTIR spectra of SG, Spirulina sp. algae biomass and ASS adsorbent 

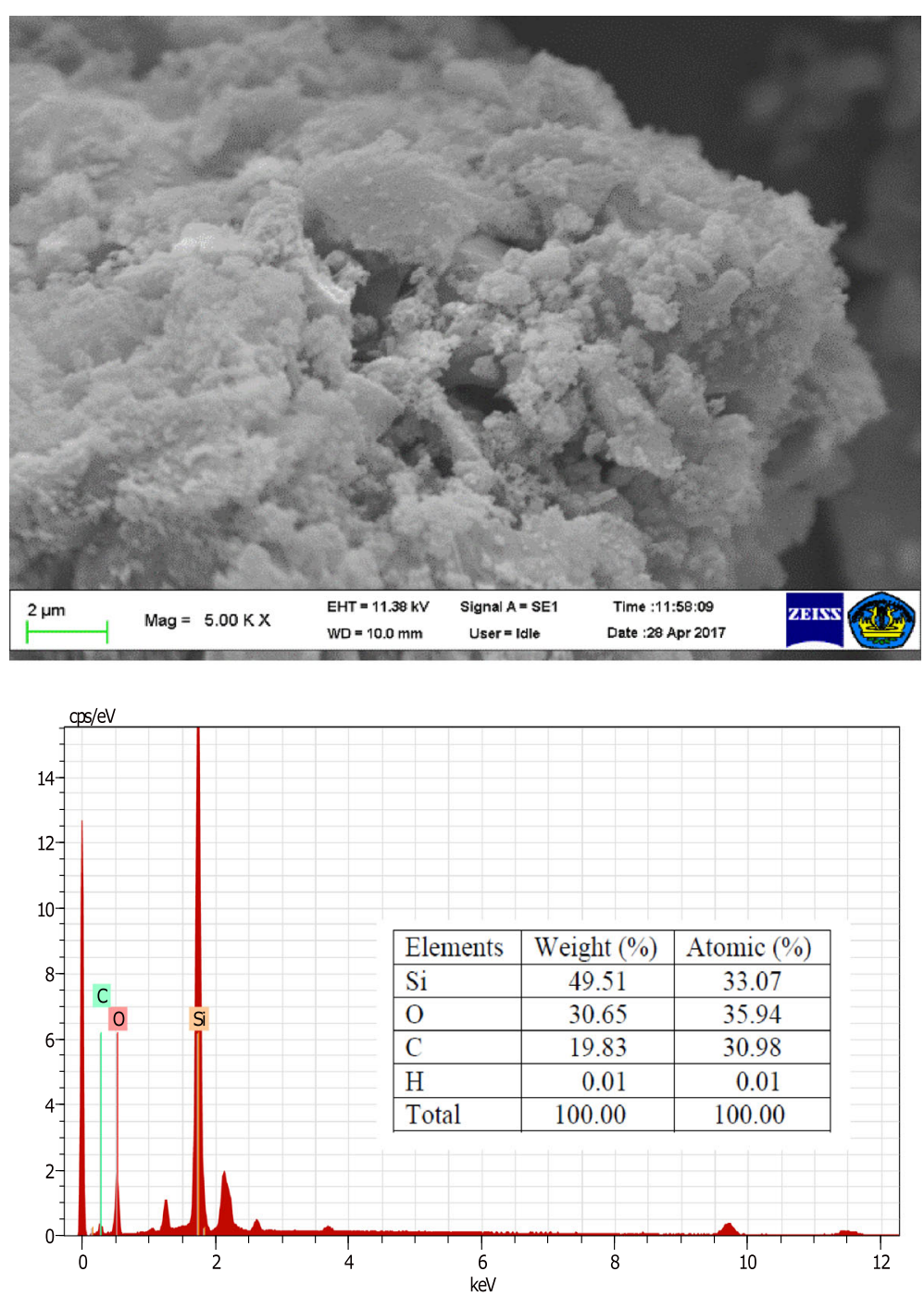

Fig. 2 Image of SEM-EDX from the ASS adsorbent

pattern of the adsorption-desorption isotherm type combined type I and IV adsorption isotherm. The type I adsorption isotherm pattern occurs in low $\mathrm{P} /$ Po regions, it is seen that the form of isotherm tends to be horizontal. Type I isotherm patterns only form one layer of adsorbate and only occur in the chemisorption process. The type IV isotherm adsorption pattern occurs in the higher $\mathrm{P} / \mathrm{Po}$ area with hysteresis loop $\mathrm{H} 1$ showing mesoporous material. The volume of adsorbates in all isotherms increased relatively sharply against $(\mathrm{P} / \mathrm{Po})$ around 0.8 which showed nitrogen capillary condensation in regular mesoporous structures. The pore size distribution of ASS derived from the adsorption branch of isotherm shows that the most probable pore size centered at $3.2 \mathrm{~nm}$. The BET surface area of ASS is $90 \mathrm{~m}^{2} \mathrm{~g}^{-1}$ with total pore volume $0.26 \mathrm{~mL} \mathrm{~g}^{-1}$ while the average pore diameters are $4.7 \mathrm{~nm}$ which is in the mesoporous scale $(2-50 \mathrm{~nm})$ [30-32].

\section{Influence of $\mathrm{pH}$}

The effect of the $\mathrm{pH}$ of the solution on $\mathrm{CV}$ and $\mathrm{MB}$ dyes has been studied by interacting $\mathrm{CV}$ and $\mathrm{MB}$ solutions at variations in $\mathrm{pH} 2-10$ (Fig. 4). In Fig. 4, it can be observed that in $\mathrm{CV}$ and $\mathrm{MB}$ solutions there is an increase in adsorption with the increase in $\mathrm{pH}$ value and the optimum adsorption occurs at $\mathrm{pH}$. $\mathrm{CV}$ and $\mathrm{MB}$ dyes are cation-based coloring agents while ASS adsorbent from Spirulina sp. biomass with silica matrix contains several functional groups such as amino, hydroxyl, and carboxyl groups derived from the algae biomass as well as silanol and siloxane groups from silica which are 


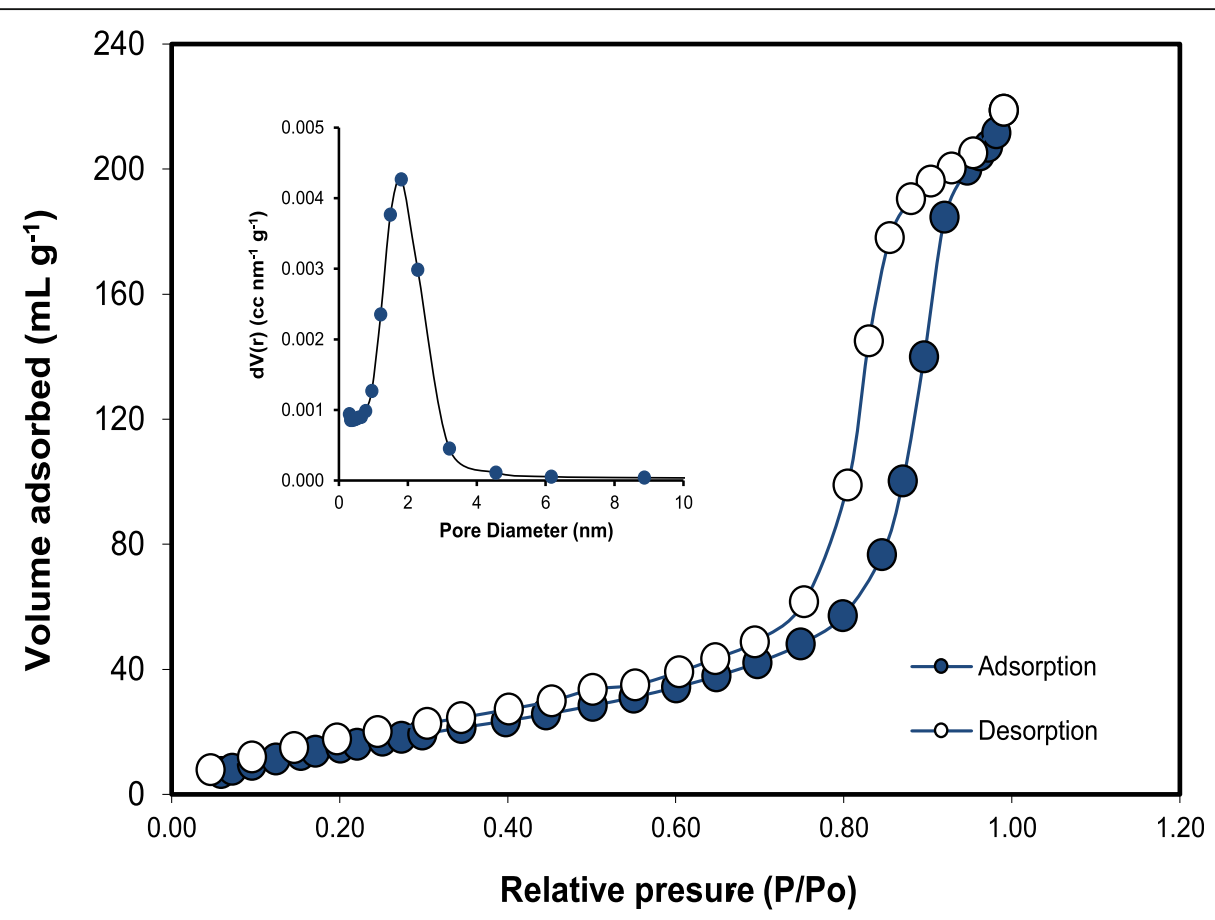

Fig. 3 The nitrogen adsorption-desorption isotherms and pore size distribution of ASS adsorbent

negative charge [24]. Therefore, at low $\mathrm{pH}$ there is competition between $\mathrm{CV}$ or $\mathrm{MB}$ molecules with protons found on the active site of ASS. As a result, the adsorption of CV and MB dyes on ASS adsorbents is not optimal [33]. Increasing the $\mathrm{pH}$ of the solution results in an increase in the amount of $\mathrm{CV}$ or $\mathrm{MB}$ dyes adsorbed, due to the increase in electrostatic interactions between $\mathrm{CV}$ or $\mathrm{MB}$ molecules [34]. At a higher $\mathrm{pH}>8$, a decrease in adsorption begins because hydroxide species (species that contain $\mathrm{OH}^{-}$ions derived from compounds present in adsorbates or adsorbents in alkaline conditions) are formed which tend to form deposits on the adsorbates and ASS adsorbents $[35,36]$. In addition, silica as the matrix of ASS is less stable at high $\mathrm{pH}$ [25],

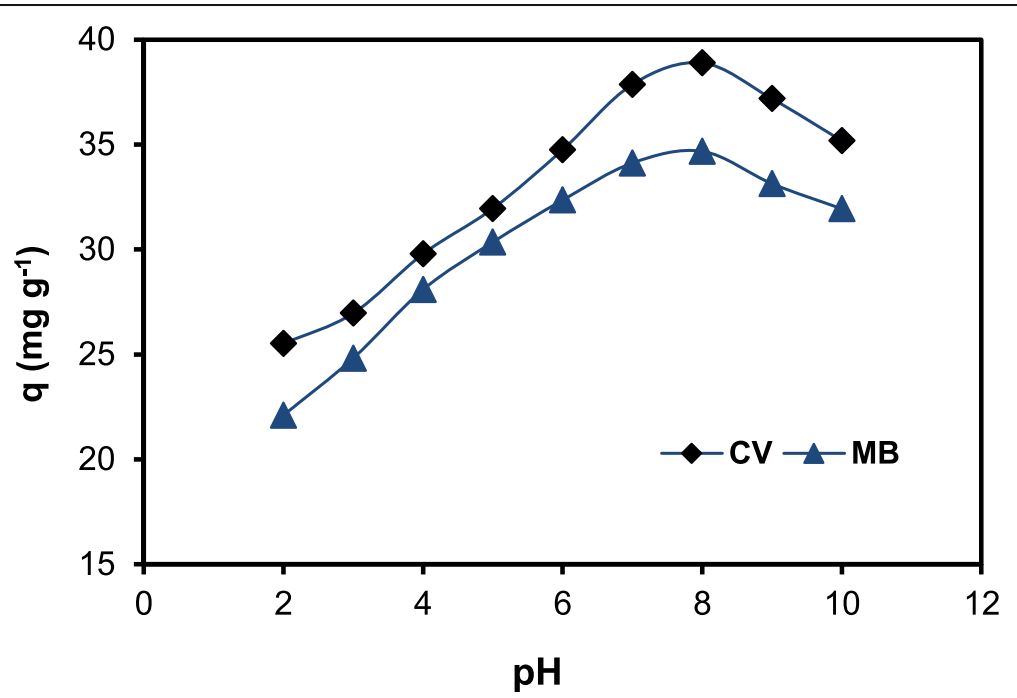

Fig. 4 Effect of the solution $\mathrm{pH}$ on the adsorption of $\mathrm{CV}$ and MB dyes by the ASS adsorbent (adsorbent dose of 50 mg, volume of adsorbate of $20 \mathrm{~mL}$, contact times of $60 \mathrm{~min}$, and temperature of $27^{\circ} \mathrm{C}$ ) 


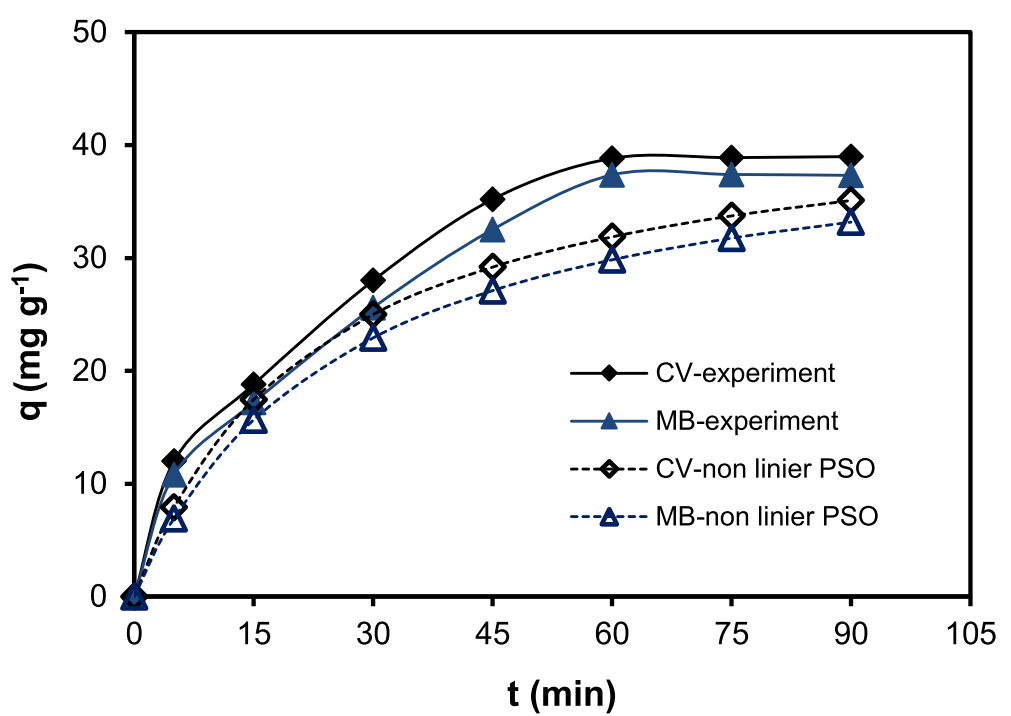

Fig. 5 Experimental data and the fitted non-linear forms of pseudo-second-order (PSO) kinetics models for the adsorption of CV and MB dyes onto ASS (adsorbent dose of $50 \mathrm{mg}$, volume of adsorbate of $20 \mathrm{~mL}$, pH of 8 , and temperature of $27^{\circ} \mathrm{C}$ )

consequently at higher $\mathrm{pH}$, the active sites on the adsorbent were damaged resulting in decreased adsorption of the $\mathrm{CV}$ or $\mathrm{MB}$ dye.

\section{Effect of contact times}

The effect of the interaction times of $\mathrm{CV}$ and $\mathrm{MB}$ dyes on the ASS adsorbent was studied by interacting CV or MB solutions to the ASS adsorbent with contact times varying from 0 to $90 \mathrm{~min}$ (Fig. 5). From Fig. 5, it can be observed that the adsorption of CV and MB dyes is relatively fast. At the first $30 \mathrm{~min}$ the adsorption increased very sharply, and then a slight increase in the adsorbed dyes and eventually reached a constant at $60-90 \mathrm{~min}$ time. At this stage the adsorption process is estimated to have reached equilibrium.

Effect of contact times of $\mathrm{CV}$ and $\mathrm{MB}$ solutions on ASS found in Fig. 5 was further analyzed to find out its kinetic model using the pseudo-first-order (Eq. 3) and pseudo-second-order (Eq. 4) kinetics models [7, 27, 37].

$$
\begin{aligned}
& \log \left(q_{e}-q_{t}\right)=\log q_{t} \frac{k_{1}}{2.303} t \\
& \frac{t}{q_{t}}=\frac{1}{k_{2} q_{e}^{2}}+\frac{t}{q_{e}}
\end{aligned}
$$

The results of the analysis using the two kinetic models show that the $\mathrm{CV}$ and $\mathrm{MB}$ dye adsorption kinetics models on the ASS adsorbent tend to follow the pseudo-second-order kinetic model (Fig. 5). This can be seen from the value of the linear regression coefficient $\left(R^{2}\right)$ in the pseudo- second-order kinetic model greater than the pseudo-first-order kinetic model (Table 1). In addition, in Fig. 5, it can be seen that the experimental data of the amount of $\mathrm{CV}$ and $\mathrm{MB}$ dyes adsorbed $(q)$ have a pattern that is relatively the same as the data of non-linear forms of pseudo-second-order kinetics models.

\section{Adsorption isotherm}

The effect of the concentration of the adsorbate plays an important role in determining the amount of adsorbate adsorbed. This is because an increase in the concentration of the adsorbate will increase its interaction with the active site of adsorbent. In this study the initial concentrations of $\mathrm{CV}$ and $\mathrm{MB}$ dyes varied from 0 to $400 \mathrm{mg} \mathrm{L}^{-1}$ which resulted in an interaction between the adsorbate and the adsorbent in the equilibrium state as shown in Fig. 6. From Fig. 6, it can be observed that there is an increase in the quantity of $\mathrm{CV}$ and $\mathrm{MB}$ dyes adsorbed with increasing concentration used. The adsorption of $\mathrm{CV}$ and $\mathrm{MB}$ dyes increased sharply at low concentrations and gradually increased at high concentrations. This shows that the ASS adsorbent has a high adsorption affinity for $\mathrm{CV}$ and $\mathrm{MB}$ dyes. The increase in adsorption is related to the number of active sites available on the surface of the adsorbent $[38,39]$.

Table 1 Kinetic parameters for the adsorption of CV and MB dyes on ASS adsorbent (adsorbent dose of $50 \mathrm{mg}$, volume of adsorbate of $20 \mathrm{~mL}$, pH of 8, and temperature of $27^{\circ} \mathrm{C}$ )

\begin{tabular}{lcccccc}
\hline & & \multicolumn{3}{c}{ Pseudo-first-order } & & \multicolumn{2}{l}{ Pseudo-second-order } \\
Adsorbates & $q_{e}\left(\mathrm{mg} \mathrm{g}^{-1}\right)$ & $k_{1}\left(\mathrm{~min}^{-1}\right)$ & $R^{2}$ & & $k_{2}\left(\mathrm{~g} \mathrm{mg}^{-1} \mathrm{~min}^{-1}\right)$ & $R^{2}$ \\
\hline MB & 44 & 0.10 & 0.870 & & 0.20 & 0.977 \\
$\mathrm{CV}$ & 43 & 0.09 & 0.974 & 0.30 & 0.960 \\
\hline
\end{tabular}




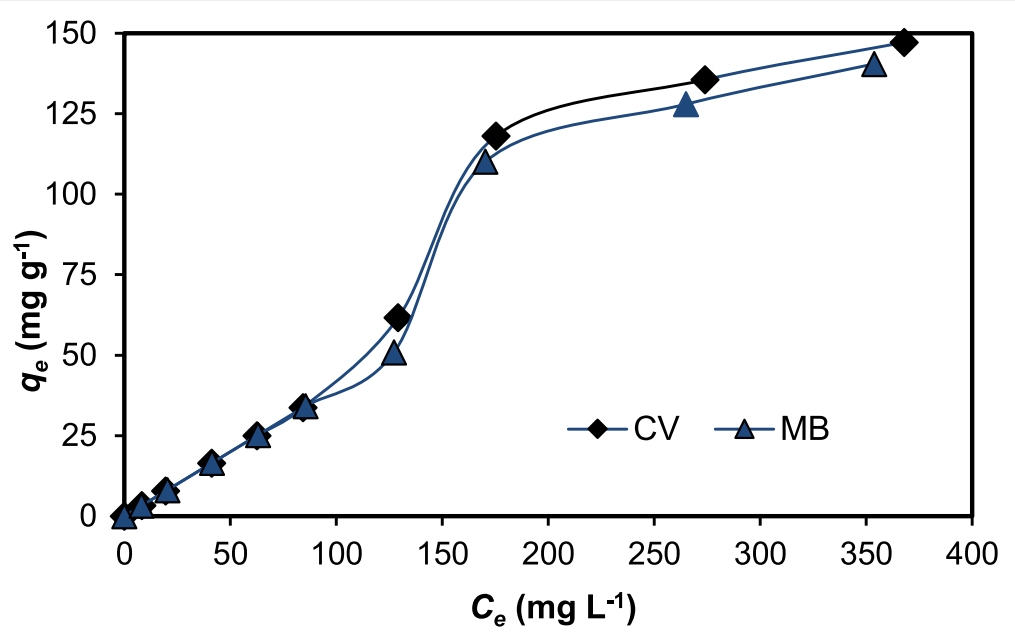

Fig. 6 Effect of the equilibrium concentration $\left(C_{e}\right)$ of $C V$ and $M B$ dyes on the amount of adsorbates adsorbed $\left(q_{e}\right)$ (adsorbent dose of $50 \mathrm{mg}$, volume of adsorbate of $20 \mathrm{~mL}$, contact time of $60 \mathrm{~min}, \mathrm{pH}$ of 8 , and temperature of $27^{\circ} \mathrm{C}$ )


Fig. 7 The linear equations of the adsorption isotherm models of the $\mathrm{CV}$ and MB dyes on the ASS adsorbent with the adsorption isotherm model of (a) Langmuir, (b) Freundlich, (c) Dubinin-Raduskevich, and (d) Temkin 
The pattern of isotherm adsorption of CV and MB dyes on the ASS adsorbent was analyzed using the Langmuir (Eq. 5), Freundlich (Eq. 6), Dubinin-Raduskevich (DR) (Eq. 7), and Temkin (Eq. 8) adsorption models [40-42]. The linear equation of each model is shown in Fig. 7. A general linear form of saturated monolayer Langmuir isotherm represented as:

$$
\frac{C_{e}}{q_{e}}=\frac{1}{q_{m} K_{L}}+\frac{C_{e}}{q_{m}}
$$

where $q_{e}\left(\mathrm{mg} \mathrm{g}^{-1}\right)$ is the amount of adsorbed adsorbate per unit weight of adsorbent and $C_{e}\left(\mathrm{mg} \mathrm{L}^{-1}\right)$ is unadsorbed adsorbate concentration in solution at equilibrium. The constant $K_{L}\left(\mathrm{~L} \mathrm{mg}^{-1}\right)$ is the Langmuir constant and $q_{m}\left(\mathrm{mg} \mathrm{g}^{-1}\right)$ gives the maximum monolayer adsorption capacity. A plot $C_{e} / q_{e}$ versus $C_{e}$ gives a slope and interceps $1 / q_{m}$ and $1 / q_{m} K_{L}$ repectively.

Freundlich adsorption isotherm illustrates that the adsorption process occurs on heterogeneous surfaces with multilayers [43]. The linear equation of the Freundlich isotherm model is shown as follows:

$$
\log q_{e}=\log K_{F}+\frac{1}{n} \log C_{e}
$$

The intercept $K_{F}$ is Freundlich constant, $n$ is Freundlich exponent obtained from the plot of $\log q_{e}$ versus $\log C_{e}$. The Freundlich exponent $n$ values were between 1 and 10 .

The DR adsorption isotherm model can be used to explain the adsorption that occurs on a homogeneous and heterogeneous surface. The DR adsorption isotherm model can be expressed as Eq. (7).

$$
\ln q_{e}=q_{D R}-2 B_{D R} R T \ln \left(1+1 / C_{e}\right)
$$

where, $R$ is the gas constant $\left(8.314 \mathrm{~kJ} \mathrm{~mol}^{-1}\right), T$ is the absolute temperature (K), $q_{D R}$ and $B_{D R}$ are the DR isotherm constants in $\mathrm{mg} \mathrm{g}^{-1}$ and $\mathrm{mo}^{2} \mathrm{~kJ}^{-2}$ respectively. Plot $\log q_{e}$ vs. $\ln \left(1+1 / C_{e}\right)$ will produce slope and intercept.

Temkin adsorption isotherm model can also be expressed in the form of linear equation as Eq. (8):

$$
q_{e}=\frac{R T}{b_{T e}} \ln \left(K_{T e} C_{e}\right)
$$

where $K_{T e}\left(\mathrm{~L} \mathrm{mg}^{-1}\right)$ is Temkin constant, $b_{T e}$ shows the heat of adsorption, $T(\mathrm{~K})$ is temperature. A plot of $q_{e}$ versus $\ln C_{e}$ are able to determine the constant $K_{T e}$. The Temkin adsorption isotherm model explains that the heat of adsorption decreases linearly as adsorbateadsorbent interactions increases [44].

The results of data analysis from the completion of linear equations in each model of adsorption isotherm in Fig. 7 in the form of adsorption parameters shown in Table 2.
Table 2 Adsorption isotherm parameters of CV and MB dyes on ASS adsorbent (adsorbent dose of $50 \mathrm{mg}$, volume of adsorbate of $20 \mathrm{~mL}$, contact time of $60 \mathrm{~min}, \mathrm{pH}$ of 8 , and temperature of $27^{\circ} \mathrm{C}$ )

\begin{tabular}{llll}
\hline Models & Parameters & \multicolumn{2}{l}{ Adsorbate } \\
\cline { 3 - 4 } & & $\mathrm{MB}$ & $\mathrm{CV}$ \\
\hline Langmuir & $q_{m}\left(\mathrm{mg} \mathrm{g}^{-1}\right)$ & 51 & 99 \\
& $K_{L} \times 10^{-2}\left(\mathrm{~L} \mathrm{mg}^{-1}\right)$ & 1.58 & 2.40 \\
& $R^{2}$ & 0.913 & 0.977 \\
Freundlich & $K_{F}\left(\left(\mathrm{mg} \mathrm{g}^{-1}\right)\left(\mathrm{L} \mathrm{mg}^{-1}\right)^{1 / n}\right)$ & 1.05 & 1.07 \\
& $n$ & 0.753 & 0.806 \\
Dubinin-Raduskevich & $R^{2}$ & 0.975 & 0.995 \\
& $\mathrm{q}_{D R}\left(\mathrm{mg} \mathrm{g}^{-1}\right)$ & 21 & 23 \\
& $\left.B_{D R} \times 10^{-6}\left(\mathrm{~mol}^{2} \mathrm{~kJ}\right)^{-2}\right)$ & -2.9 & -2.7 \\
Temkin & $R^{2}$ & 0.892 & 0.963 \\
& $b_{T e}\left(\mathrm{~J} \mathrm{~mol}^{-1}\right)$ & 12.49 & 12.32 \\
& $K_{T e}\left(\mathrm{Lg}^{-1}\right)$ & 2.06 & 2.08 \\
& $R^{2}$ & 0.606 & 0.738 \\
\hline
\end{tabular}

From Table 2, it can be observed that the parameters of the linear equation regression coefficient $\left(R^{2}\right)$ of $\mathrm{CV}$ and MB dyes adsorption by ASS for the Freundlich adsorption isotherm model (at interaction time of $60 \mathrm{~min}$, interaction $\mathrm{pH}$ of 8 and temperature of $27^{\circ} \mathrm{C}$ ) are 0.995 and 0.975 , respectively. This shows that the adsorption isotherms of $\mathrm{CV}$ and $\mathrm{MB}$ dyes are more in accordance with the models of Freundlich adsorption. The Freundlich adsorption isotherm illustrates that the adsorption process of the $\mathrm{CV}$ and $\mathrm{MB}$ dyes occurs on heterogeneous surfaces with multilayers [43]. Furthermore, in the Langmuir adsorption isotherm model, it is assumed that on the surface of the adsorbent there are a certain number of active sites that are proportional to the surface area, the surface of the adsorbent is uniform and the adsorption process is monolayer $[45,46]$. Thus it can be stated that the adsorption process of $\mathrm{CV}$ and $\mathrm{MB}$ dyes that occur in the ASS adsorbent involves physical and chemical adsorption [47]. The physical adsorption occurs through pores contained in the ASS adsorbent while the chemical adsorption occurs through active sites derived from the active groups of Spirulina sp. algae biomass $(-\mathrm{OH},-\mathrm{N}-\mathrm{H}$, and $-\mathrm{C}=\mathrm{O})$ and silica matrix (-Si-OH, $-\mathrm{O}-\mathrm{Si}-\mathrm{O}-)$.

The ability of ASS adsorbent to absorb CV and MB dyes in a single adsorption process (Figs. $4,5,6$ ) shows that $\mathrm{CV}$ dye is relatively absorbed more compared to MB. This is in line with the kinetics data found in Table 1 which shows the rate constant $\left(k_{2}\right)$ of the pseudo-second-order kinetics model in $\mathrm{CV}$ dyes greater than that of $\mathrm{MB}$ dye. The data are also supported by simultaneous adsorption data of $\mathrm{CV}$ and MB dyes on the ASS adsorbent shown in Fig. 8. The data show that the ASS adsorbent is relatively more 


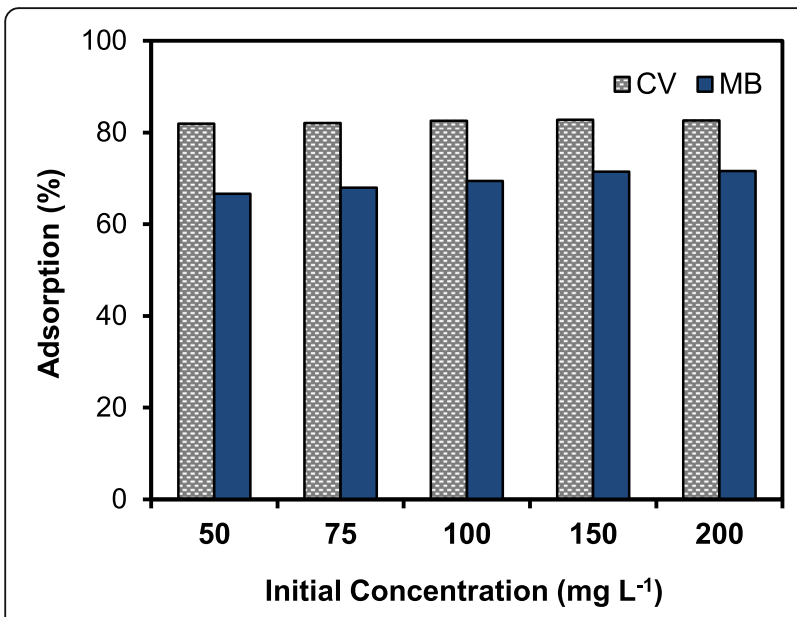

Fig. 8 Simultaneous adsorption of CV and MB dyes on ASS adsorbents (adsorbent dose of $50 \mathrm{mg}$, volume of adsorbate of 20 $\mathrm{mL}$, concentrations of the adsorbate mixture are $50-200 \mathrm{mg} \mathrm{L}^{-1}$, contact time of $60 \mathrm{~min}, \mathrm{pH}$ of 8 , and temperature of $27^{\circ} \mathrm{C}$ ) suitable for the CV dye, if competed simultaneously. In the simultaneous adsorption process which is binary adsorption, there are three possible interactions that occur, namely: synergism, antagonism, and non-interaction [48]. Therefore, the difference in size and molecular structure between $\mathrm{CV}$ and $\mathrm{MB}$ dyes causes a difference in reactivity to the ASS adsorbent when competed together. This is in line with the studies that have been reported on $\mathrm{CV}$ and $\mathrm{MB}$ dyes removal from aqueous solutions using the fly ash-based adsorbent material-supported zerovalent iron [49].

\section{Reuse of adsorbents}

The ability of adsorbents to be used repeatedly in the adsorption process is one of the important factors needed to determine the effectiveness of an adsorbent. In this study, repeated use of ASS adsorbent in adsorbing $\mathrm{CV}$ and $\mathrm{MB}$ dye solutions was studied by absorbing $\mathrm{CV}$ and $\mathrm{MB}$ dyes adsorbed sequentially using water and $0.1 \mathrm{M} \mathrm{HCl}$ solution as an eluent (Fig. 9). From Fig. 9 it can be observed that the use of 3 repetitions of ASS adsorbents did not reduce the amount of dyes adsorbed significantly (\% of the dye adsorbed $>80 \%$ ) but the capability of the adsorbent decreased in the 4th adsorption repetition. Desorption of $\mathrm{CV}$ and $\mathrm{MB}$ dyes with water was carried out to release $\mathrm{CV}$ and $\mathrm{MB}$ dyes adsorbed through physical interactions which illustrated the contribution of the trap mechanism in the adsorbent pores [53]. Furthermore, desorption with $\mathrm{HCl}$ solution is effective as an eluent for releasing $\mathrm{CV}$ and $\mathrm{MB}$ molecules from adsorbents by substituting protons against $\mathrm{CV}$ or MB molecules as organic cations [54].

If the results of this study are compared with other adsorbents to adsorb CV and MB dyes (Table 3), it can be

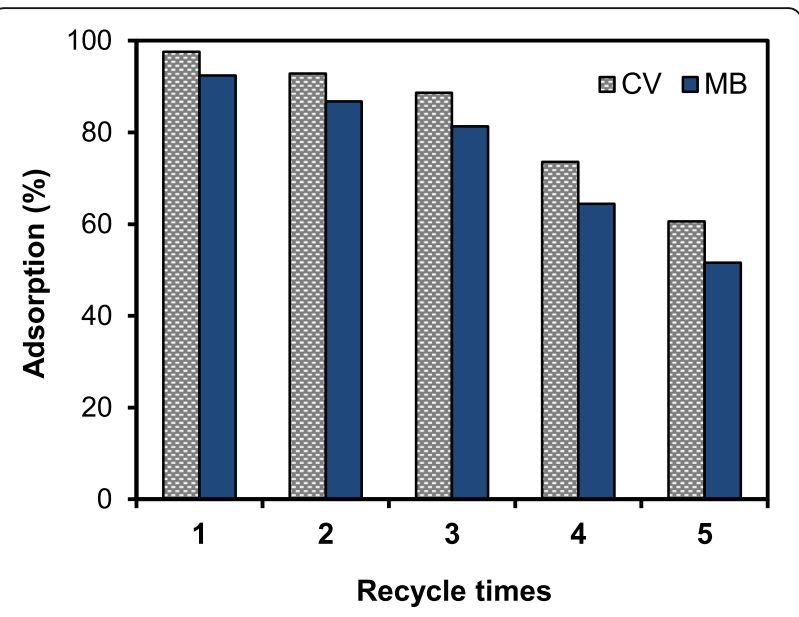

Fig. 9 Reuse the ASS adsorbent on the adsorption of CV and MB dyes (adsorbent dose of $50 \mathrm{mg}$, adsorbate concentration of $200 \mathrm{mg}$ $\mathrm{L}^{-1}$, volume of adsorbate of $20 \mathrm{~mL}$, contact time of $60 \mathrm{~min}, \mathrm{pH}$ of 8 , and temperature of $27^{\circ} \mathrm{C}$ )

stated that the ASS adsorbent has advantages because the $\mathrm{CV}$ and $\mathrm{MB}$ dyes adsorption processes are dominated by physical interactions, consequently $\mathrm{CV}$ and $\mathrm{MB}$ dyes adsorbed are easy to be released. So that the impact of its use on processing of dye waste in industry will be more effective because the adsorbent can be used repeatedly. Economic factors are one of the main considerations in planning of waste treatment systems in the industry. The cost of using algae biomass will be cheaper than synthetic adsorbent because its availability in nature is quite abundant. Besides that the remaining adsorbent that has been used do not cause problems in the environment because the ASS adsorbent contains algae that is easily degraded.

\section{Conclusions}

The ASS adsorbent derived from hybridization of Spirulina sp. algae biomass with silica as matrix for removal of $\mathrm{CV}$ and $\mathrm{MB}$ dyes in the solution was successfully carried out. The CV and MB dye kinetics models on the ASS adsorbent follow the pseudo-second-order kinetics and the Freundlich adsorption isotherm model. The ASS adsorbent is an effective adsorbent for removing CV dyes in solution compared to MB dye, both in single adsorption process and simultaneous adsorption. The findings from this research are summarized as follows:

1. The FTIR spectra show that the hybridization process occurs between the Spirulina sp. algae biomass and silica as the supporting matrix.

2. The analysis results of surface morphology with SEM show the surface morphology of the ASS adsorbent in the form of amorphous solid. 
Table 3 Comparison of several adsorbents for CV and MB dyes

\begin{tabular}{|c|c|c|c|c|c|}
\hline Adsorbents & $a_{m} \subset V\left(\mathrm{mg} \mathrm{g}^{-1}\right)$ & References & Adsorbents & $\begin{array}{l}q_{m} \mathrm{MB} \\
\left(\mathrm{mg} \mathrm{g}^{-1}\right)\end{array}$ & References \\
\hline Phosphoric acid activated carbon (PAAC) & 60 & [4] & Algae Porphyridium sp.-silica- $\mathrm{Fe}_{3} \mathrm{O}_{4}$ hybrid & 97 & {$[14]$} \\
\hline Sol gel $\mathrm{SiO}_{2} / \mathrm{Nb}_{2} \mathrm{O}_{5}(\mathrm{SiNb})$ & 116 & {$[10]$} & Silica-Polymer hybrid & 87 & [33] \\
\hline Formosa papaya seed powder & 86 & {$[50]$} & $\mathrm{Fe}_{3} \mathrm{O}_{4} @ \mathrm{MIL}-100(\mathrm{Fe})$ magnetite composite & 74 & [43] \\
\hline Rice husk activated carbon & 11 & [51] & Magnetite loaded multi-wall carbon nanotubes & 48 & {$[52]$} \\
\hline ASS (CV initial concentration of $200 \mathrm{mg} \mathrm{L}^{-1}$ ) & 78 & This work & ASS (MB initial concentration of $200 \mathrm{mg} \mathrm{L}^{-1}$ ) & 74 & This work \\
\hline
\end{tabular}

3. In the EDX spectrum there are several elements that dominate the material composition of ASS, namely the elements of $\mathrm{Si}, \mathrm{O}, \mathrm{C}$, and $\mathrm{H}$, indicating that hybridization between the silica matrix and the Spirulina sp. algae biomass.

4. The BET surface area of ASS is $90 \mathrm{~m}^{2} \mathrm{~g}^{-1}$ and the total pore volume of ASS is $0.26 \mathrm{~mL} \mathrm{~g}^{-1}$ while the average pore diameter is $4.74 \mathrm{~nm}$.

5. The isotherm adsorption pattern of $\mathrm{CV}$ and $\mathrm{MB}$ dyes follows the Freundlich adsorption isotherm, and the use of 3 repetitions of ASS adsorbents does not reduce the amount of dye adsorbed significantly (\% of the dye adsorbed $>80 \%$ ).

\section{Acknowledgements}

This research was supported and funded by the Directorate of Research and Community Service, Directorate General for Research and Development, Ministry of Research, Technology and Higher Education of the Republic of Indonesia with contract number: 065/SP2H/LT/DPRM/2019. The researchers also express a high appreciation to Technical Service Unit of the Integrated Laboratory and the Technology Innovation Center-University of Lampung (UPT Laboratorium Terpadu dan Sentra Inovasi Teknologi-Universitas Lampung) for the support of the instruments used in this study.

\section{Authors' contributions}

The manuscript was mainly based on a draft written by Buhani and Suharso, and written through contributions of all authors. All authors read and approved the final manuscript.

\section{Funding}

This work was funded by Ministry of Research, Technology and Higher Education of the Republic of Indonesia with contract number: 065/SP2H/LT/ DPRM/2019.

\section{Availability of data and materials}

The datasets generated during and/or analyzed during the current study are available from the corresponding author on reasonable request.

\section{Competing interests}

The authors declare that they have no competing interests.

\section{Author details}

${ }^{1}$ Department of Chemistry, University of Lampung, Bandar Lampung 35145 Indonesia. ${ }^{2}$ Department of Electrical Engineering, University of Lampung, Bandar Lampung 35145, Indonesia.

Received: 14 May 2019 Accepted: 9 September 2019

Published online: 21 October 2019

\section{References}

1. Guler UA, Ersan M, Tuncel E, Dugenci F. Mono and simultaneous removal of crystal violet and safranin dyes from aqueous solutions by HDTMA-modified Spirulina sp. Process Saf Environ. 2016;99:194-206.
2. Forgacs E, Cserhati T, Oros G. Removal of synthetic dyes from wastewaters: a review. Environ Int. 2004;30:953-71.

3. Gupta GS, Prasad G, Panday KK, Singh VN. Removal of chrome dye from aqueous solutions by fly ash. Water Air Soil Poll. 1988;37:13-24.

4. Senthilkumaar S, Kalaamani P, Subburaam CV. Liquid phase adsorption of crystal violet onto activated carbons derived from male flowers of coconut tree. J Hazard Mater. 2006;136:800-8.

5. Garg VK, Kumar R, Gupta R. Removal of malachite green dye from aqueous solution by adsorption using agro-industry waste: a case study of Prosopis cineraria. Dyes Pigments. 2004;62:1-10.

6. Ahmad A, Rafatullah M, Sulaiman O, Ibrahim MH, Hashim R. Scavenging behaviour of meranti sawdust in the removal of methylene blue from aqueous solution. J Hazard Mater. 2009;170:357-65.

7. Kittappa S, Pichiah S, Kim JR, Yoon Y, Snyder SA, Jang M. Magnetised nanocomposite mesoporous silica and its application for effective removal of methylene blue from aqueous solution. Sep Purif Technol. 2015;153:67-75.

8. Dardouri S, Sghaier J. A comparative study of adsorption and regeneration with different agricultural wastes as adsorbents for the removal of methylene blue from aqueous solution. Chinese J Chem Eng. 2017;25:1282-7.

9. Mona S, Kaushik A, Kaushik CP. Waste biomass of Nostoc linckia as adsorbent of crystal violet dye: optimization based on statistical model. Int Biodeterior Biodegradation. 2011;65:513-21.

10. Umpierres CS, Prola LDT, Adebayo MA, Lima EC, dos Reis GS, Kunzler DDF, et al. Mesoporous $\mathrm{Nb}_{2} \mathrm{O}_{5} / \mathrm{SiO}_{2}$ material obtained by sol-gel method and applied as adsorbent of crystal violet dye. Environ Technol. 2017;38:566-78.

11. Vaiano V, Sacco O, Sannino D, Ciambelli P. Nanostructured N-doped $\mathrm{TiO}_{2}$ coated on glass spheres for the photocatalytic removal of organic dyes under UV or visible light irradiation. Appl Catal B-Environ. 2015;170:153-61.

12. Saitoh $T$, Saitoh $M$, Hattori $C$, Hiraide M. Rapid removal of cationic dyes from water by coprecipitation with aluminum hydroxide and sodium dodecyl sulfate. J Environ Chem Eng. 2014;2:752-8.

13. Weber CT, Collazzo GC, Mazutti MA, Foletto EL, Dotto GL. Removal of hazardous pharmaceutical dyes by adsorption onto papaya seeds. Water Sci Technol. 2014:70:102-7.

14. Buhani, Hariyanti F, Suharso, Rinawati, Sumadi. Magnetized algae-silica hybrid from Porphyridium sp. biomass with $\mathrm{Fe}_{3} \mathrm{O}_{4}$ particle and its application as adsorbent for the removal of methylene blue from aqueous solution. Desalin Water Treat. 2019:142:331-40.

15. Wu JS, Liu CH, Chu KH, Suen SY. Removal of cationic dye methyl violet 2B from water by cation exchange membranes. J Membrane Sci. 2008; 309:239-45.

16. Suharso, Buhani. Biosorption of $\mathrm{Pb}(\mathrm{II}), \mathrm{cu}(\mathrm{II})$ and $\mathrm{cd}(\mathrm{II})$ from aqueous solution using cassava peel waste biomass. Asian J Chem. 2011;23:1112-6.

17. Buhani, Herasari D, Suharso, Yuwono SD. Correlation of ionic imprinting cavity sites on the amino-silica hybrid adsorbent with adsorption rate and capacity of $\mathrm{Cd}^{2+}$ ion in solution. Orient J Chem. 2017;33:418-29.

18. Angelova R, Baldikova E, Pospiskova K, Maderova Z, Safarikova M, Safarik I. Magnetically modified Sargassum horneri biomass as an adsorbent for organic dye removal. J Clean Prod. 2016;137:189-94.

19. Daneshvar E, Vazirzadeh A, Niazi A, Kousha M, Naushad M, Bhatnagar A. Desorption of methylene blue dye from brown macroalga: effects of operating parameters, isotherm study and kinetic modeling. J Clean Prod. 2017:152:443-53.

20. Harris PO, Ramelow GJ. Binding of metal ions by particulate biomass derived from Chorella vulgaris and Scenedesmus quadricauda. Environ Sci Technol. 1990;24:220-8. 
21. Veglio F, Beolchini F, Toro L. Kinetic modeling of copper biosorption by immobilized biomass. Ind Eng Chem Res. 1998;37:1107-11.

22. Volesky B, Holan ZR. Biosorption of heavy metals. Biotechnol Prog. 1995;11: $235-50$

23. Buhani, Suharso, Satria H. Hybridization of Nannochloropsis sp. biomass-silica through sol-gel process to adsorb Cd (II) ion in aqueous solutions. Eur J Sci Res. 2011;51:467-76.

24. Buhani, Rinawati, Suharso, Yuliasari DP, Yuwono SD. Removal of Ni (II), Cu (II), and Zn (II) ions from aqueous solution using Tetraselmis sp. biomass modified with silica-coated magnetite nanoparticles. Desalin Water Treat. 2017:80:203-13

25. Buhani, Suharso, Aprilia L. Chemical stability and adsorption selectivity on $\mathrm{Cd}^{2+}$ ionic imprinted Nannochloropsis sp. material with silica matrix from tetraethyl orthosilicate. Indo J Chem. 2012;12:94-9.

26. Buhani, Musrifatun, Pratama DS, Suharso, Rinawati. Modification of Chaetoceros sp. biomass with silica-magnetite coating and adsorption studies towards Cu (II) ions in single and binary system. Asian J Chem. 2017; 29:2734-8.

27. Buhani S, Fitriyani AY. Comparative study of adsorption ability of Ni (II) and Zn (II) ionic imprinted amino-silica hybrid toward target metal in solution. Asian J Chem. 2013:25:2875-80

28. Machado RSA, da Fonseca MG, Arakaki LNH, Espinola JGP, Oliveira SF. Silica gel containing sulfur, nitrogen and oxygen as adsorbent centers on surface for removing copper from aqueous/ethanolic solutions. Talanta. 2004;63:317-22.

29. Yang $H, X u R$, Xue XM, Li FT, Li GT. Hybrid surfactant templated mesoporous silica formed in ethanol and its application for heavy metal removal. J Hazard Mater. 2008;152:690-8.

30. Oscik J. Adsorption. New York: Wiley; 1983

31. Liang YD, He YJ, Wang TT, Lei LH. Adsorptive removal of gentian violet from aqueous solution using $\mathrm{CoFe}_{2} \mathrm{O}_{4} /$ /activated carbon magnetic composite. J Water Process Eng. 2019;27:77-88.

32. Cho DW, Lee J, OK YS, Kwon EE, Song H. Fabrication of a novel magnetic carbon nanocomposite adsorbent via pyrolysis of sugar. Chemosphere. 2016;163:305-12.

33. Jamwal HS, Kumari S, Chauhan GS, Reddy NS, Ahn JH. Silica-polymer hybrid materials as methylene blue adsorbents. J Environ Chem Eng. 2017;5:103-13.

34. Zhang QL, Lu T, Bai DM, Lin DQ, Yao SJ. Self-immobilization of a magnetic biosorbent and magnetic induction heated dye adsorption processes. Chem Eng J. 2016;284:972-8.

35. Gupta VK, Rastogi A. Biosorption of lead from aqueous solutions by green algae Spirogyra species: kinetics and equilibrium studies. J Hazard Mater. 2008:152:407-14.

36. Buhani, Puspitarini M, Suharso R, Rilyanti M, Sumadi. Adsorption of phenol and methylene blue in solution by oil palm shell activated carbon prepared by chemical activation. Orient J Chem. 2018;34:2043-50.

37. Araghi SH, Entezari MH. Amino-functionalized silica magnetite nanoparticles for the simultaneous removal of pollutants from aqueous solution. Appl Surf Sci. 2015;333:68-77.

38. Atar N, Olgun A, Wang SB. Adsorption of cadmium (II) and zinc (II) on boron enrichment process waste in aqueous solutions: batch and fixed-bed system studies. Chem Eng J. 2012;192:1-7.

39. AbdEl-Salam AH, Ewais HA, Basaleh AS. Silver nanoparticles immobilised on the activated carbon as efficient adsorbent for removal of crystal violet dye from aqueous solutions. A kinetic study. J Mol Liq. 2017;248:833-41.

40. Ho YS, Porter JF, Mckay G. Equilibrium isotherm studies for the sorption of divalent metal ions onto peat: copper, nickel and lead single component systems. Water Air Soil Poll. 2002;141:1-33.

41. Peric J, Trgo M, Medvidovic NV. Removal of zinc, copper and lead by natural zeolite—a comparison of adsorption isotherms. Water Res. 2004;38:1893-9.

42. Montazer-Rahmati MM, Rabbani P, Abdolali A, Keshtkar AR. Kinetics and equilibrium studies on biosorption of cadmium, lead, and nickel ions from aqueous solutions by intact and chemically modified brown algae. J Hazard Mater. 2011;185:401-7.

43. Shao YM, Zhou LC, Bao C, Ma JJ, Liu MZ, Wang F. Magnetic responsive metal-organic frameworks nanosphere with core-shell structure for highly efficient removal of methylene blue. Chem Eng J. 2016;283:1127-36.

44. Allen SJ, Mckay G, Porter JF. Adsorption isotherm models for basic dye adsorption by peat in single and binary component systems. J Colloid Interf Sci. 2004;280:322-33.
45. Xin X, Wei Q, Yang J, Yan L, Feng R, Chen G, et al. Highly efficient removal of heavy metal ions by amine-functionalized mesoporous $\mathrm{Fe}_{3} \mathrm{O}_{4}$ nanoparticles. Chem Eng J. 2012;184:132-40.

46. Larraza I, Lopez-Gonzalez M, Corrales T, Marcelo G. Hybrid materials: magnetite-Polyethylenimine-montmorillonite, as magnetic adsorbents for $\mathrm{Cr}$ (VI) water treatment. J Colloid Interf Sci. 2012;385:24-33.

47. Li FW, Wu XA, Ma SJ, Xu ZJ, Liu WH, Liu F. Adsorption and desorption mechanisms of methylene blue removal with iron-oxide coated porous ceramic filter. J Water Resour Prot. 2009;1:1-57.

48. Guler UA, Sarioglu M. Mono and binary component biosorption of $\mathrm{Cu}(\mathrm{II}), \mathrm{Ni}$ (III), and methylene blue onto raw and pretreated S. cerevisiae: equilibrium and kinetics. Desalin Water Treat. 2014;52:4871-88.

49. Liu JW, Wang YM, Fang Y, Mwamulima T, Song SX, Peng CS. Removal of crystal violet and methylene blue from aqueous solutions using the fly ashbased adsorbent material-supported zero-valent iron. J Mol Liq. 2018;250: 468-76.

50. Pavan FA, Camacho ES, Lima EC, Dotto GL, Branco VTA, Dias SLP. Formosa papaya seed powder (FPSP): preparation, characterization and application as an alternative adsorbent for the removal of crystal violet from aqueous phase. J Environ Chem Eng. 2014;2:230-8.

51. Mohanty K, Naidu JT, Meikap BC, Biswas MN. Removal of crystal violet from wastewater by activated carbons prepared from rice husk. Ind Eng Chem Res. 2006;45:5165-71.

52. Ai LH, Zhang CY, Liao F, Wang Y, Li M, Meng LY, et al. Removal of methylene blue from aqueous solution with magnetite loaded multi-wall carbon nanotube: kinetic, isotherm and mechanism analysis. J Hazard Mater. 2011;198:282-90.

53. Buhani, Suharso, Rilyanti M, Sumadi. Implementation of sequential desorption in determining $\mathrm{Cd}$ (II) ion interaction with adsorbent of ionic imprinting amino-silica hybrid. Rasayan J Chem. 2018;11:865-70.

54. Varghese SP, Babu AT, Babu B, Antony R. Y-MnOOH nanorods: efficient adsorbent for removal of methylene blue from aqueous solutions. J Water Process Eng. 2017:19:1-7.

\section{Publisher's Note}

Springer Nature remains neutral with regard to jurisdictional claims in published maps and institutional affiliations.
Ready to submit your research? Choose BMC and benefit from:

- fast, convenient online submission

- thorough peer review by experienced researchers in your field

- rapid publication on acceptance

- support for research data, including large and complex data types

- gold Open Access which fosters wider collaboration and increased citations

- maximum visibility for your research: over $100 \mathrm{M}$ website views per year

At BMC, research is always in progress.

Learn more biomedcentral.com/submissions 